\title{
Quality of ultra-high temperature treated milk available in Gazipur and Mymensingh of Bangladesh
}

\author{
MY Arafat ${ }^{1}$, R Habib ${ }^{2 *}$, MSR Siddiki ${ }^{2}$, MF I mam ${ }^{3}$ \\ ${ }^{1}$ BRAC Dairy and Food Project, Gazipur; ${ }^{2}$ Department of Dairy Science, ${ }^{3}$ Department of Agricultural Statistics, \\ Bangladesh Agricultural University, Mymensingh 2202, Bangladesh
}

\begin{abstract}
This experiment was conducted to evaluate the quality of existing ultra-high temperature (UHT) treated milk available in two selected town markets of Bangladesh. A total of 27 UHT milk samples from three different brands-Pran Dairy (A), Aarong Dairy (B) and Farm Fresh (C) were collected from local markets at Mymensingh and Gazipur districts during the period of $1^{\text {st }}$ September to $29^{\text {th }}$ November, 2014. Parameters studied in this experiment were organoleptic (flavour, consistency, colour and appearance), physic-chemical (specific gravity, acidity, total solids, solids-not-fat, fat, protein, lactose, and ash) and microbiological (Total Viable Count and Coliform Count). All the samples were similar in respect of color, flavor, taste and texture, and no significant difference was observed. However, significant differences were revealed $(p<0.05)$ in case of specific gravity, acidity, total solids, solids-not-fat, and protein content. On the other hand, insignificant differences were found $(p>0.05)$ in case of fat, lactose, and ash content. Total Viable Count and Coliform count were found to be nil in all the milk samples. Milk samples of Farm Fresh UHT milk were superior to other brands of UHT Milk in terms of contents of total solids $(119.23 \pm 0.57 \mathrm{~g} / \mathrm{kg})$, fat $(34.97 \pm 0.35 \mathrm{~g} / \mathrm{kg})$, lactose $(43.23 \pm 0.51 \mathrm{~g} / \mathrm{kg})$, and ash $(7.00 \pm 0.26 \mathrm{~g} / \mathrm{kg})$. Though there were some fluctuations in all the parameters studied, all the milk samples conformed to the standard values for UHT milk, and in general all of the UHT milk samples studied in this experiment was of good quality.
\end{abstract}

Key words: UHT milk, quality, markets, Bangladesh.

Bangladesh Animal Husbandry Association. All rights reserved. Bang. J. Anim. Sci. 2015.44 (3): $132-136$

\section{Introduction}

Milk is a highly nutritious food (Kim et al., 1983). It is a complex mixture of fat, protein, carbohydrates, minerals, vitamins and other miscellaneous constituents dispersed in water, making it a complete diet. Average composition of bovine milk is $87.2 \%$ water, $3.7 \%$ fat, $3.5 \%$ protein, $4.9 \%$ lactose and $0.7 \%$ minerals (Haug et al., 2007). Raw milk can be a source of many harmful pathogens, causing a number of diseases like undulant fever, dysentery, salmonellosis, tuberculosis, etc. To overcome this problem, milk is subjected to heat treatment of various intensities like pasteurization, sterilization, and ultra-high temperature treatment. Ultra-high temperature (UHT) processing heats the milk at a temperature of $138^{\circ} \mathrm{C}$ for a few seconds destroys all microbes present in milk as well as inactivates all the enzymes, thus gives the milk a better shelf-life and a more acceptable sensory perception (Bylund, 1995).

\section{*Corresponding Author: raihanh46@yahoo.com}

Proteolysis of UHT milk during storage at room temperature is a major factor limiting the shelf life through changes in its flavor and texture. The changes ultimately reduce the quality and limit the shelf life of UHT milk via development of offflavors, fat separation and sedimentation, which principally falls into two categories, liberation of volatile fatty acids such as butyric acid and oxidation of free or unsaturated fatty acids (Datta et al. 2002). Clare et al. (2005) observed that sweet aromatic flavor and sweet taste of UHT milk decreased during storage. The microorganisms, that cause spoilage in milk, which is intended to be sterile after UHT treatment, may be present if resistant types have survived the heat treatment, ororganisms contaminate the product after the sterilization process. The quality of milk is a major issue in Bangladesh. The UHT milk is becoming more popular due to ease of storage. Though a number of dairy processing companies are now supplying 
Arafat et al. (2015) Bang. J. Anim. Sci. 44(3): 132- 136

long shelf-life UHT milk, no research work has ever been focused on testing the quality of the product. So, this study was undertaken with the aim of investigating the quality of UHT milk available at local markets of Gazipur and Mymensingh towns in Bangladesh.

\section{Materials and Methods}

The experiment was conducted at the Dairy Chemistry and Microbiology Laboratory of the Department of Dairy Science, Bangladesh Agricultural University, Mymensingh and Quality Assurance Laboratory of Aarong Dairy, Teen Sarak, Laxmipura, Gazipur during the period of 1st October to $15^{\text {th }}$ December, 2014. UHT milk samples were collected randomly from local markets of Gazipur and Mymensingh Towns. The available UHT milk samples were: Pran UHT Milk, Aarong UHT Milk and Farm Fresh UHT Milk designated as A, B and C, respectively. Three samples from each brand were collected in each of the three trails, a total of 27 samples were collected. Samples were analyzed by a panel of experienced judges for organoleptic scores (flavor, consistency, color and appearance), chemical composition $(\mathrm{pH}$, contents $(\mathrm{g} / \mathrm{kg})$ of total solids, fat, solids-not-fat, protein, carbohydrate, and ash), microbiological qualities (total viable count, and coliform count). The Analysis of variance was done as using completely Randomized Design (Steel et al., 1997) by the MSTATC statistical package. Least significant difference values were also determined to rank the samples.

\section{Results and Discussion}

The sensory parameters studied were flavor, consistency, and color and appearance. Flavor scores of UHT milk obtained from PRAN, Aarong, and Farm Fresh were 37.67 $\pm 2.52,41.67 \pm 5.77$ and $43.67 \pm 3.21$, respectively (Table 1 ). Flavor scores of all the collected UHT milk samples were similar i.e. sweet aromatic flavor. Judkins (1960) reported that milk produced under proper hygienic condition had mild aromatic flavor and slightly sweet taste. However, all the samples developed slightly cooked flavor, which might be due to Maillard Reaction. Walstra et al. (2006) described the mechanism of pigment production in milk as a result of intense heat treatment, which explains the reason of cooked flavor developed in the experimental milk samples.

Consistency scores of UHT milk obtained from PRAN, Aarong, and Farm Fresh were24.00 \pm 2.00 , $26.00 \pm 1.73$ and $28.00 \pm 2.00$, respectively with no significant differences (Table 1 ). All the samples showed a liquid consistency with free flowing property.

Color and appearance scores of UHT milks obtained from PRAN, Aarong, and Farm Fresh were $16.00 \pm 1.73,18.00 \pm 2.00$ and $18.67 \pm 2.31$, respectively (Table 1 ). Color and texture of the collected UHT milk samples was similar i.e. slightly brownish white. Eckles et al. (1951) stated that the color of milk ranges from a bluishwhite to yellowish white, depending on the breed of animal, kind of feed used amount of fat and total solids present. The color of the experimental samples was different, probably due to intense heat treatment. However, all the samples were acceptable in quality.

Specific gravity of UHT milks obtained from PRAN, Aarong, and Farm Fresh were1.027 \pm 0.00 , $1.028 \pm 0.001$ and $1.029 \pm 0.001$, respectively (Table 2). It was found that there was insignificant difference among the specific gravity values. Islam et al. (1984) reported that the mean of specific gravity of milk of Bangladesh Agricultural University Dairy Farm was 1.031 and that of milk from local markets was 1.026. Alam (1998) found the specific gravity of milk samples from Aftab fresh milk was 1.036. So, the specific gravity of the experimental samples were on the lower limit of the range which might be due to breed of cattle and processing technique applied.

Acidity percentages of the experimental samples were $0.15 \pm 0.01,0.15 \pm 0.01$ and $0.14 \pm 0.00$, respectively (Table 2 ). It was found that there was a significant difference $(p<0.05)$ among the samples. The values of acidity of Arong UHT milk and Pran UHT (0.15) were higher than that of Farm Fresh UHT milk. The acidity of normal milk samples was within the range of 0.10 to .018 percent with an average of 0.16 percent (Early, 1998). So, the acidity values were within the normal range for the experimental samples. 


\section{Quality of ultra- high temperature treated milk}

Table 1. Organoleptic parameters of UHT milks available in Gazipur and Mymensingh of Bangladesh.

\begin{tabular}{|c|c|c|c|c|}
\hline \multirow[t]{2}{*}{ Organoleptic parameter } & \multicolumn{3}{|c|}{ Score obtained (Mean \pm SD) } & \multirow{2}{*}{$\begin{array}{c}\text { Level of } \\
\text { significance }\end{array}$} \\
\hline & $\begin{array}{c}\text { Sample A } \\
\text { (Pran) }\end{array}$ & Sample B (Aarong) & $\begin{array}{c}\text { Sample C } \\
\text { (Farm Fresh) }\end{array}$ & \\
\hline Flavor (50) & $37.67 \pm 2.52$ & $41.67 \pm 5.77$ & $43.67 \pm 3.21$ & NS \\
\hline Consistency (30) & $24.00 \pm 2.00$ & $26.00 \pm 1.73$ & $28.00 \pm 2.00$ & NS \\
\hline Color and Appearance (20) & $16.00 \pm 1.73$ & $18.00 \pm 2.00$ & $18.67 \pm 2.31$ & NS \\
\hline
\end{tabular}

NS, not significant

The higher acidity of sample A and B were probably due to initial high acidities of the raw milk.

Fat contents of UHT milk obtained from Pran, Aarong, and Farm Fresh were34.73 \pm 0.51 , $34.63 \pm 0.35$ and $34.97 \pm 0.35 \quad(\mathrm{~g} / \mathrm{kg})$, respectively (Table 2 ). There was an insignificant difference $(p<0.05)$ among the fat contents of collected UHT milk sample. The fat content of Farm Fresh brand was the highest with almost perfect composition. According to De (1980), milk should contain minimum 3.5\% fat. The average fat percentages of these experimental samples were slightly lower than the recommended values. The lower fat content might be due to partial skimming or withdrawal of fat before processing or collection of raw milk with low fat content.

Protein content of UHT milks obtained from Pran, Aarong, and Farm Fresh were $32.77 \pm 0.42, \quad 34.07 \pm 0.40$ and $33.93 \pm 0.45$ $(\mathrm{g} / \mathrm{kg})$, respectively (Table 2$)$. It was found that there were significant differences $(p<0.05)$ among the protein contents of collected UHT milk samples. The average value of protein content obtained from Arong UHT milk sample was the highest, whereas that of Pran UHT milk was the lowest. The result agrees with the work of Filiptovic (1953) found that the average values of protein in UHT milk ranges from 3.33 $\%$ to $3.52 \%$. Lactose content of UHT milks of the experimental samples were $42.80 \pm 0.60$, $43.60 \pm 0.56$ and $43.23 \pm 0.51 \quad(\mathrm{~g} / \mathrm{kg})$, respectively (Table 2 ). It was found that there were insignificant differences among the Lactose contents. Generally milk contains (4.74.9) \% lactose (Jennes and Patton, 1959). Walstra et. al. (2007) reported that the lactose content in milk shows very minor variation because this parameter is relatively stable. Ash contents of UHT milk obtained from Pran, Aarong and Farm Fresh were 6.73 \pm 0.55 , $6.73 \pm 0.32$ and $7.00 \pm 0.26(\mathrm{~g} / \mathrm{kg})$ respectively (Table 2) and there were insignificant differences among the values. Ali (1999) reported that the average ash content of milk samples collected from BAU Dairy Farm and different other milk suppliers ranged from $0.673 \pm 0.01$ to $0.714 \pm 0.02$, which agrees with the findings of this research. Solids-not-fat contents of UHT milk obtained from Pran, Aarong, and Farm Fresh were82.30 0.44 , $84.40 \pm 0.66$ and $84.27 \pm 0.76 \quad(\mathrm{~g} / \mathrm{kg})$, respectively (Table 2 ) with a significant differences $(p<0.05)$. The average value of SNF content obtained from Arong UHT milk was higher than those of other brands. Hossain (1984) reported that the average SNF percentage of milk collected from local markets of Bangladesh was $8.91 \pm 0.25 \%$. Alam (1998) found that the \%SNF of milk samples from Aftab Fresh milk was $8.43 \%$. However, the standard value of SNF of cow milk is $8.5 \%$ (FDA, 2009). So, the SNF contents of the experimental samples were slightly low, which indicates adulteration by water, though very small.

Total solids contents of UHT milk obtained from Pran, Aarong, and Farm Fresh were $117.03 \pm 0.71,119.03 \pm 0.64$ and 119.23 \pm 0.57 $(\mathrm{g} / \mathrm{kg})$, respectively (Table 2$)$. There was a significant differences $(p<0.05)$ among the total solids contents of collected UHT milk samples. It was founded that the values of TS content obtained from Farm Fresh UHT milk sample was the highest and that of Pran UHT milk was the lowest. However, all the samples showed values slightly less than normal, as cow milk should contain more than $12 \%$ Total solids (FDA, 2009). 
Arafat et al. (2015) Bang. J. Anim. Sci. 44(3): 132- 136

Table 2. Physical and chemical parameters of UHT milks available in Gazipur and Mymensingh of Bangladesh.

\begin{tabular}{lccccc}
\hline \multirow{2}{*}{$\begin{array}{c}\text { Chemical } \\
\text { parameters }\end{array}$} & \multicolumn{3}{c}{ Composition (Mean \pm SD) } & $\begin{array}{c}\text { LSD } \\
\text { value }\end{array}$ & $\begin{array}{c}\text { Level of } \\
\text { significance }\end{array}$ \\
\cline { 2 - 4 } & $\begin{array}{c}\text { Sample A } \\
\text { (Pran) }\end{array}$ & $\begin{array}{c}\text { Sample B } \\
\text { (Aarong) }\end{array}$ & $\begin{array}{c}\text { Sample C } \\
\text { (Farm Fresh) }\end{array}$ & & \\
\hline Specific gravity & $1.027 \pm 0.00$ & $1.028 \pm 0.01$ & $1.029 \pm 0.01$ & - & NS \\
Acidity $(\%)$ & $0.15^{\mathrm{a}} \pm 0.01$ & $0.15^{\mathrm{a}} \pm 0.01$ & $0.14^{\mathrm{b}} \pm 0.00$ & 0.297 & $*$ \\
$\mathrm{TS}(\mathrm{g} / \mathrm{kg})$ & $117.03^{\mathrm{b}} \pm 0.71$ & $119.03^{\mathrm{a}} \pm 0.6$ & $119.23^{\mathrm{a}} \pm 0.57$ & 1.283 & $*$ \\
$\mathrm{SNF}(\mathrm{g} / \mathrm{kg})$ & $82.30^{\mathrm{b}} \pm 0.44$ & $84.40^{\mathrm{a}} \pm 0.66$ & $84.27^{\mathrm{a}} \pm 0.76$ & 1.26 & $*$ \\
Fat $(\mathrm{g} / \mathrm{kg})$ & $34.73 \pm 0.51$ & $34.63 \pm 0.35$ & $34.97 \pm 0.35$ & - & NS \\
Protein $(\mathrm{g} / \mathrm{kg})$ & $32.77^{\mathrm{b}} \pm 0.42$ & $34.07^{\mathrm{a}} \pm 0.40$ & $33.93^{\mathrm{a}} \pm 0.45$ & 0.847 & $*$ \\
Lactose $(\mathrm{g} / \mathrm{kg})$ & $42.80 \pm 0.60$ & $43.60 \pm 0.56$ & $43.23 \pm 0.51$ & - & $\mathrm{NS}$ \\
Ash $(\mathrm{g} / \mathrm{kg})$ & $6.73 \pm 0.55$ & $6.73 \pm 0.32$ & $7.00 \pm 0.26$ & - & NS \\
\hline
\end{tabular}

$a, b, c$ In a row figures with different superscripts differ significantly: $*=p<0.05, N S=$ Not significant

Islam et al. (1984) found that the milk collected from BAU Dairy Farm contained $12.50 \mathrm{~g} / \mathrm{kg}$ total solids. Both Total Viable and Coliform Counts (colony forming unit/ml) of Pran UHT milk, Aarong UHT milk and Fram Fresh UHT milk were found to be nil. This could be attributed to ultrahigh temperature $\left(137-141^{\circ} \mathrm{C}\right)$ treatment and aseptic packaging.

\section{Conclusion}

All the samples were good in terms of organoleptic and microbial qualities. All the samples were acceptable in terms of acidity and specific gravity. Considering all the parameters, it could be concluded that the overall acceptability of UHT milk supplied by Aarong was better, followed by Farm Fresh. However, none of the samples meet the standards of whole milk in terms of total solids, solids-not-fat and fat contents. Therefore, it is recommended that the manufacturers should standardize the raw milk during processing.

\section{References}

Alam MM (1998). Study on the quality of raw milk produced by individual farmers and mixed milk collected from different centers of four Thana of Kisoregonj district under Aftab Bahumukhi Farm Limited. M.S. Thesis submitted to the Department of Dairy science, Bangladesh Agricultural University, Mymensingh.
Ali MS (1999). A study on the quality of milk consumed by students different halls and residential people of Bangladesh agricultural University, Mymensingh. M.S. Thesis submitted to the Department of Dairy science, Bangladesh Agricultural University, Mymensingh.

Bylund G (1995). Dairy processing hand book. Tetra Pak Processing Systems AB. S22186, Lund, Sweden.

Clare, DA, Bang WS, Cartwright G, Drake MA, Coronel P, and Simunovic J (2005). Comparison of sensory, microbiological, and biochemical parameters of micro wave verses indirect UHT fluid skim milk during storage. Journal of Dairy Science, 88:41724182.

Datta N, Elliot AJ, Perkin $\mathrm{ML}$, and Deeth $\mathrm{HC}$ (2002). UHT treatment of milk: comparison of direct and indirect methods of heating. Australian Journal of Dairy Technology. 57(3): 211-257.

De S (1980). Outlines of dairy technology. $1^{\text {st }}$ edition. New Delhi: Oxford Press.

Early R (1998). The Technology of Dairy Products, $2^{\text {nd }}$ edition. pp. 32-37.

FDA (2009). Grade 'A' pasteurized milk ordinance. Food and Drugs Administration, USA.

Filiptovic DJ (1953). Milk quality determination in connection with standardization of normal milk. Dairy Science Abstracts, 16: 1014.

Haug A, Hostmark AT, and Harstad OM (2007). Bovine milk in human nutrition are view. Lipids in Health and Disease, 6:25. 


\section{Quality of ultra- high temperature treated milk}

Islam MN, Hossain SML, Mannan AKMA (1984). Studies on the physical parameters and chemical qualities of market milk in Mymensingh town. Bangladesh Journal of Animal science, 13, (1\&2): 52-56.

Jenness R and Patton S (1959). Principle of dairy chemistry. New York: J ohn Wiley \& Sons.

Judkins HF, Keener HA (1960). Milk production and processing. John Wiley \&Sons Inc., New York, pp: 27-41.

Kim H, Hardy J, Novak G, Ramet JP, and Weber F (1983). Off-tastes in raw and reconstituted milk. FAO Animal Production and Health Paper, 35: 2.

Kim JW (1995). Studies on the bacteriological condition in the milking environment. Korean Journal of Dairy Science, 17(2): 113-122, 36.

Steel RGD, Torrie JH, Dickey DA (1997). Principles and procedure of statistics: a biometrical approach. $3^{\text {rd }}$ edition. New York: The McGraw-Hill Companies, Inc.

Walstra P, Wouters JTM, and Geurts TJ (2006). Dairy Science and Technology. $2^{\text {nd }}$ editon. New York: CRC Press. 